\title{
Severe progressive brain involvement in a patient with TRMT10C mutation
}

\author{
Comprometimento cerebral progressivo grave em paciente com mutação no gene TRMT10C \\ Clara Gontijo CAMELO', André Macedo Serafim SILVA', Antônio José ROCHA², Vinicius SCARAMUZZI', \\ Cristiane de Araújo Martins MORENO'1, Umbertina Conti REED'1 Edmar ZANOTELI'1
}

A 2-month-old girl presented hypotonia, followed by progressive cognitive and motor deterioration, pyramidal signs, hearing loss, refractory epilepsy, and high serum lactate level. A biceps brachii biopsy presented cytochrome c oxidase negative fibers, and serial brain magnetic resonance imaging (MRI) showed progressive brain involvement (Figure 1). Whole-exome sequencing showed the homozygous pathogenic variant c.542G>T (p.Arg181Leu) in TRMT10C. The nuclear gene TRMTC10C encodes RNase P protein responsible for mt-tRNA maturation and causes an autosomal recessive mitochondrial disease ${ }^{1}$. To our knowledge, variants in TRMT10C have only been described once in two patients presenting hypotonia, lactic acidosis, and sensorineural deafness, but the brain imaging progression pattern was never depicted ${ }^{2}$.
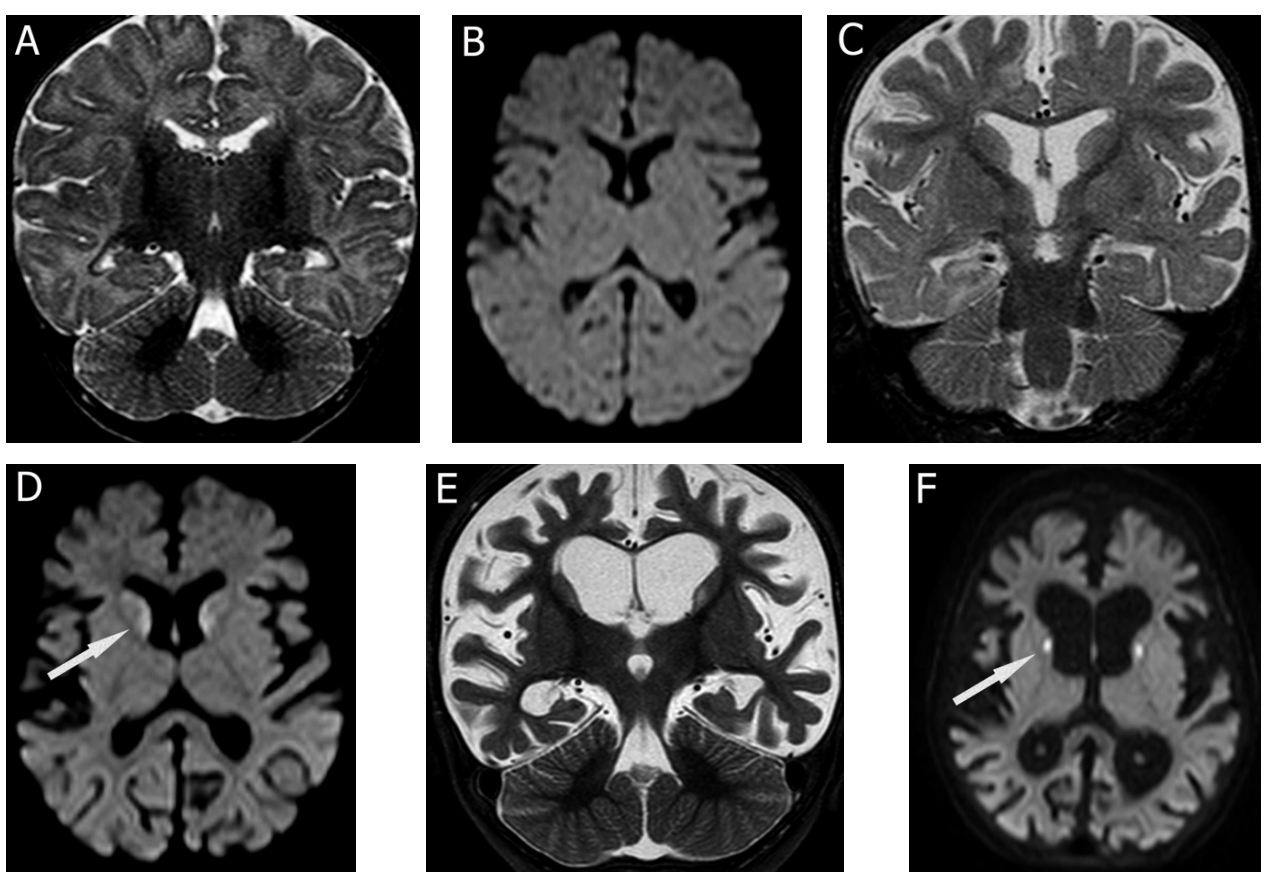

Figure 1. Comparative images for follow-up demonstrating rapidly progressive generalized brain atrophy. Comparative coronal images on fluid attenuated inversion recovery [FLAIR] ( $A, C$ and $E$ ) and Axial plane images on T2 FSE sequence (B, D, and F) were obtained when the patient was 3,8 , and 13 months of age, respectively, showing predominantly involvement of supratentorial regions, particularly affecting the white matter and superficial cortex with progressive enlargement of sulci and ventricular dilation. Deep gray matter has less evident atrophy with selective abnormal basal ganglia T2/FLAIR hyperintensity (arrows). This striatal abnormality has particularly involved the head of caudate nuclei and anterior parts of putamen, and was more evident in the last examination.

\footnotetext{
1Universidade de São Paulo, Faculdade de Medicina, Departamento de Neurologia, São Paulo SP, Brazil.

${ }^{2}$ Alta Excelência Diagnóstica (Grupo DASA), Seção de Neurorradiologia, São Paulo SP, Brazil.

Clara Gontijo CAMELO (D) https://orcid.org/0000-0002-2319-8027; André Macedo Serafim SILVA (DD https://orcid.org/0000-0002-5792-5878; Antônio José ROCHA (D) https://orcid.org/0000-0002-4358-4750; Vinicius SCARAMUZZI (DD https://orcid.org/0000-0002-3056-2878;

Cristiane de Araújo Martins MORENO (iD https://orcid.org/0000-0002-5867-6359; Umbertina Conti REED (D) https://orcid.org/0000-0001-7014-0349; Edmar ZANOTELI (D) https://orcid.org/0000-0002-4991-6760

Correspondence: Edmar Zanoteli; E-mail:edmar.zanoteli@usp.br

Conflict of Interest: There is no conflict of interest to declare.

Authors' contributions: CGC: acquisition, analysis, and interpretation of the data. AMSS, AJR, VS, CAMM, UCR: interpretation of the data and critical revision of the manuscript. EZ: analysis and interpretation of the data and critical revision of the manuscript.

Received on July 22, 2020; Received in its final form on August 9, 2020; Accepted on August 13, 2020.
} 


\section{References}

1. Lia de la Sierra-Gallay I, Pellegrini O, Condon C. Structural basis for substrate binding, cleavage and allostery in the tRNA maturase RNase Z. Nature. 2005 Feb;433(7026):657-61. https://doi. org/10.1038/nature03284
2. Metodiev MD, Thompson K, Alston CL, Morris AAM, He L, Assouline Z, et al. Recessive mutations in TRMT10C cause defects in mitochondrial RNA processing and multiple respiratory chain deficiencies. Am J Hum Genet. 2016 May;98(5):993-1000. https://doi.org/10.1016/j.ajhg.2016.03.010 